IZA DP No. 6960

Fame and the Fortune of Academic Economists: How the Market Rewards Influential Research in Economics

Christiana E. Hilmer

Michael J. Hilmer

Michael R. Ransom

October 2012 


\title{
Fame and the Fortune of Academic Economists: How the Market Rewards Influential Research in Economics
}

\author{
Christiana E. Hilmer \\ San Diego State University \\ Michael J. Hilmer \\ San Diego State University \\ Michael R. Ransom \\ Brigham Young University \\ and IZA
}

\section{Discussion Paper No. 6960 \\ October 2012}

\author{
IZA \\ P.O. Box 7240 \\ 53072 Bonn \\ Germany \\ Phone: +49-228-3894-0 \\ Fax: +49-228-3894-180 \\ E-mail: iza@iza.org
}

\begin{abstract}
Any opinions expressed here are those of the author(s) and not those of IZA. Research published in this series may include views on policy, but the institute itself takes no institutional policy positions. The IZA research network is committed to the IZA Guiding Principles of Research Integrity.

The Institute for the Study of Labor (IZA) in Bonn is a local and virtual international research center and a place of communication between science, politics and business. IZA is an independent nonprofit organization supported by Deutsche Post Foundation. The center is associated with the University of Bonn and offers a stimulating research environment through its international network, workshops and conferences, data service, project support, research visits and doctoral program. IZA engages in (i) original and internationally competitive research in all fields of labor economics, (ii) development of policy concepts, and (iii) dissemination of research results and concepts to the interested public.
\end{abstract}

IZA Discussion Papers often represent preliminary work and are circulated to encourage discussion. Citation of such a paper should account for its provisional character. A revised version may be available directly from the author. 
IZA Discussion Paper No. 6960

October 2012

\begin{abstract}
Fame and the Fortune of Academic Economists: How the Market Rewards Influential Research in Economics*

We analyze the pay and position of 1,009 faculty members who teach in doctoral-granting economics departments at fifty-three large public universities in the United States. Using the Web of Science, we have identified the journal articles published by these scholars and the number of times each of these articles has been subsequently cited in published research articles. We find that research influence, as measured by various measures of total citations, is a surprisingly strong predictor of the salary and the prestige of the department in which professors are employed. We also examine how coauthorship is rewarded by the market.
\end{abstract}

JEL Classification: J31, J44

Keywords: academic labor markets, professor's salaries

Corresponding author:

Michael Ransom

Department of Economics

143 FOB

Brigham Young University

Provo, UT 84602

USA

E-mail: ransom@byu.edu

\footnotetext{
* We thank James Wood for helpful research assistance. We are also grateful for helpful comments by Stephen Woodbury and participants of seminars at Tulane University, the Society of Labor Economists (2012), the Western Economic Association meetings (2012), and the Southern California Conference in Applied Microeconomics (2012).
} 


\section{Introduction}

A primary responsibility of professors at research universities is to produce new and useful knowledge. In a world where universities compete for the best researchers, we expect that those whose work is most important or influential will be able to command the highest salaries and that they will find employment at the best universities, where their skills will be most valued.

Labor economists who study the academic labor market have long been interested in the question of how to best measure the influence of an individual's research. Most early attempts to identify the effect of research quality measured this simply by counting the number of publications, perhaps distinguishing by type, such as in Tuckman and Leahy (1975) or Tuckman, Gapinski and Hagemann (1977). Later refinements examined whether publications in more prestigious journals counted more in the academic labor market, as in Siegfried and White(1973) or Katz (1973).

The advent of citations databases, especially the Social Sciences Citation Index (SSCl) and the Science Citation Index ( $\mathrm{SCl}$ ), has made it possible to use citation counts as a way to measure the influence of an article or its author. Perhaps the first of these was Holtmann and Bayer (1970) who studied young PhDs in the natural sciences, using a count of citations in the Science Citation Index as one of several determinants of salary. An influential early paper that studied the pay of economists was Hamermesh, Johnson and Weisbrod (1982). Others who have used citation counts to explain academic salaries are Bratsberg, Ragan and Warren (2010), Sauer (1988), Moore, Newman and Turnbull (2001), and Diamond (1986). All of these articles find that citations substantially influence salaries.

Two recent articles have much in common with our work here. Hamermesh and Pfann (2011) (HP) use total citation counts from the $\mathrm{SSCl}$ to explain a variety of outcomes for a sample of full professors at 88 US economics departments. These outcomes include whether a professor was elected a Fellow of the Econometric Society, the prestige of the department at which the professor works, as well as the professor's salary. Hamermesh and Pfann pose the question in terms of quantity and quality 
of publications - with quantity measured by the number of articles published, and quality being measured by the number of citations to those articles. Generally, they find that citations are an important determinant of "reputation" while numbers of publications are not. However, salary is apparently determined by both the quantity and quality of publications. Ellison (2010) uses citation counts from Google Scholar. He analyzes a sample of "young tenured economists" at the top 25 US economics departments, and explains the rank of an individual's department using that individual's Hirsch index as an explanatory variable. (We discuss the Hirsch index in detail below.) He finds that the Hirsch index (or some generalization of it) provides a better fit to the data than traditional measures of citation counts.

In this paper, we undertake analyses similar to those described in HP and Ellison. That is, we explore how an individual's citations history affects that individual's pay and position. Our approach differs most markedly in that we analyze all faculty members, not just full professors or tenured professors. We also have a somewhat larger and more consistent sample than HP, although they have more schools in some of their analyses. Our sample also better represents the spectrum of quality of economics departments in the US, ranging from rank 104 to rank 7 according to the 1995 National Research Council rankings.

\section{On Measuring "Influence"}

Are citations the right way to measure the influence of someone's research? Posner (2000) describes a variety of reasons why an author would cite someone else's work. He asserts that the majority of citation in science and social science is to recognize the "priority" of the cited author's method, discovery, argument or way of describing something. Citations of this sort are exactly what we mean by influence in social science. In some cases, this influence may actually be negative. One might 
write an article to refute the article that is cited, for example. Still, the article has influenced others to think about the ideaand such controversy has an important role in science.

On the other hand, citations may be motivated for strategic reasons that have nothing to do with the influence of the article that is cited. An author might want to flatter a potential referee or editor, for example. Cole (2000) discusses some other aspects of the controversy with using citations to measure impact. Despite potential limitations, the use of citation counts to measure the importance or influence of an article is now widely accepted. Furthermore, it has been shown to be a powerful factor for explaining things like salaries.

\section{Data}

\section{A. Salary and Biographical Data}

Because individual salary information is rather difficult to obtain, previous studies of salary determination in the profession have relied on fairly limited samples. Among recent examples, Bratsberg, Ragan, and Warren (2003) analyze panel data on 176 tenure-track faculty at five identified Midwestern universities while Moore, Turnbull, and Newman (1998) analyze cross-sectional data on 142 tenure-track faculty at nine unidentified state universities. According to the authors themselves, the universities in both of those studies could be considered mid-level and thus as noted in Moore, Turnbull, and Newman "one should not infer that our empirical results generalize to the Top 20 programs." This is unfortunate, as salary determination within the profession likely does differ across the program quality distribution and by repeated moving/staying decisions.

Beyond the legwork involved, there is little to prevent a researcher from compiling a much more sizable and detailed faculty salary data set that enables comparisons across the program quality distribution while providing more extensive individual-level information. The 1966 Freedom of Information Act (FOIA) gave citizens the power to request a substantial amount of information from 
federal government files. While the law did not apply to state governments, most states have since enacted their own FOIA policies that enable citizens to request state government records. As such, it should be possible to compile faculty salary data on the vast majority of public universities in the U.S. Because our focus is Ph.D.-granting programs, in August 2007 we began requesting salary data for faculty members at the 68 public programs listed among the 1995 NRC Rankings of the top 106 U.S. Ph.D.-granting economics programs. In response, we received reliable current salary information from the 53 programs listed in table 1 . As indicated there, our current sample reflects a much more complete cross-section of the profession than those analyzed in previous studies and the current sample of 1,009 individuals (excluding those with administration appointments) for whom we can collect sufficient individual background characteristics is a vast improvement on the samples previously studied. ${ }^{1}$

To these data we added biographical details that we collected from on-line CVs and biographies, including their academic rank, the date of hire at their current institution, the year in which they earned the Ph. D., and their gender.

\section{B. Publications and Citations Data}

We collected all the information on publications and their citations through the end of 2006 from the Web of Science (WOS), an online database that is owned by Thompson Reuters. We identified all the listed publications in the Web of Science for each of the individuals in our salary sample, using the search tools available. This is a labor-intensive undertaking, as we must separate the publications of individuals who have similar names. For most entries in WOS, the name is listed by last name and initials of given names. For individuals like Daniel Hamermesh, there is no confusion. On the other

\footnotetext{
${ }^{1}$ Our sample is quite comparable to that used by Hamermesh and Pfann (2011). For their salary analysis, they collected data from 43 public institutions, mostly for the 2007-2008 academic year. However, for some of the schools in their sample, they used data from other years, inflating or deflating by a factor of 1.04 for each year. Furthermore, they collect information only for full professors. In the end, they have a sample of 564 professors with salary data. Our sample contains 570 full professors.
} 
hand, we had to distinguish between well known economists James C. Cox (who is in our sample) and John C. Cox (who is not). We did this by comparing CVs with the list of articles in our WOS search result, and restricting search on the basis of known affiliations during the professor's career. We also examined our resulting list of publications on the basis of field, journal titles, and article titles. There is the potential for errors of both inclusion and exclusion.

The Web of Science consists of three datasets --Science Citation Index-Expanded, Social Science Citations Index, and Arts and Humanities Citation Index. These datasets contain articles published in a large but select set of journals. Many journals indexed in EconLit, for example, are not indexed in SSCl. ${ }^{2}$ However, all of the well-known economics journals are included, and it is unlikely that we have understated the influence of an individual's contributions by much.

Books or chapters in books are not included. However, we have included all types of entries in WOS. While we refer to them as articles, in some cases these are items such as editorials, editorial introductions to special issues, book reviews, or conference proceedings. We collected information from all three of the WOS datasets. Although the bulk of articles by economists in our sample is in journals indexed by $\mathrm{SSCl}$, some important work by economists appears in the sciences or engineering journals. For example, the second most cited article in our sample is a paper by Hal White that appears in Neural Networks, a journal that is indexed in $\mathrm{SCl}$ but not in $\mathrm{SSCl}$. (The article had more than 2,500 citations through 2006.)

Tables 2 and 3 provide summary information about the underlying articles that are used in our sample. These tables examine only unique articles-articles may be used multiple times to compute individual cumulative citations in our sample if more than one of the coauthors of the paper is in our

\footnotetext{
${ }^{2}$ See Garfield (1990) for a discussion of how journals are selected for inclusion in the Web of Science databases. Klein and Chiang (2004) argue that there is an ideological bias in the selection of journals to the SSCl.
} 
sample. Publication years range from 1956 to 2006, but the vast majority of the articles were published after 1980. There are on average 1.8 authors per article, with maximum number of $16 .^{3}$

The average number of citations for these articles is 12.84 , but total citations are extremely skewed in distribution, as shown in Table 3. The median article had only 3 citations. More than 30 percent of articles are not cited at all. In part this can be explained by the fact that some of the entries are short book reviews and introductions to special issues or the like, and the author would not have expected them to be cited. On the other hand, a book review could be quite influential, so we have not excluded these types of publications ex ante. Another reason that some are not cited is because they are too recently published. Sadly, this does not make a huge difference. For articles at least six years old, more than 25 percent have not been cited. A simple linear regression with intercept yields a slope estimate of about 0.5 . The median article is cited about once every four years. Relatively speaking, an article that has been cited 10 times is very successful, and one that has been cited more than 50 times is outstanding. (For comparison, the single most cited article has more total citations than all of the least cited 9,000 articles.)

The standard citations database is the Web of Science, parts of which have existed since the 1960s. However, alternatives have started to appear. One is Google Scholar, an online service created by the web search giant. It uses robot search programs to identify scholarly work that is available on the web and to collect citations data from it. The advantage of Google Scholar is that it defines influence more broadly-its sources include working papers and books, as well as published articles in journals. Potentially, it indexes more journals than Web of Science, as well. The disadvantage is that it is hard to know exactly what its universe is. Exactly which articles are indexed? How does it treat multiple versions of a working paper, some of which will undoubtedly have different titles? Should citations by

\footnotetext{
${ }^{3}$ While a few entries in the WOS for our professors had more than 16 authors, we determined that these were all entries such as conference reports that listed all attendees, or letters to the editor with all signatories listed as authors. We therefore eliminated these entries from our sample.
} 
papers that will never be published be counted equally with those that are published after peer review? A casual comparison of several articles suggests that Google Scholar citation counts are 2 to 10 times more than Web of Science counts.

SCOPUS is another online research service operated by the publisher Elsevier that may have citations capability. RePec (Research Papers in Economics) is set of online databases and programs that is mostly volunteer effort. As it uses authors to identify their own papers, it has the potential to be very accurate. It focuses on citations in economics articles, only. At this time, its coverage is not complete enough to do the sort of analysis presented here.

\section{Aggregate Citations and the Hirsch Index}

The typical way to aggregate citation counts to articles is to simply sum the citation counts of all the articles that an individual has written. However, because this aggregate citation count is highly skewed, and because a single article typically contributes a large part the total, it is sensible to summarize an individual's citation record in a way that somehow reduces the impacts of articles in the upper tail. We have adopted two approaches. The first is the logarithm of the aggregate citations plus one. (Adding one is necessary because a significant number of those in our sample have no citations.) The second method we use is to compute the Hirsch index (or h-index) for each individual.

The h-index has been suggested as a "particularly simple and useful way to characterize the scientific output of a researcher." (Hirsch, 2005) Consider a researcher who has N publications. If h of those publications have each been cited at least $\mathrm{h}$ times, while the other $\mathrm{N}$-h publications have each been cited less than $\mathrm{h}$ times, then he or she has an index value of $\mathrm{h}$. An intuitive way to think of this index is that it is a count of the number of "important" papers, where the level of importance increases with the number of papers. Thus someone with an $\mathrm{h}$ value of 5 has 5 papers of relatively little impact, while someone with an $\mathrm{h}$ of 30 has 30 papers of very high impact. (Recall that a paper with 30 citations 
is at the $90^{\text {th }}$ percentile of the papers in our sample.) Ellison (2010) has suggested a generalization of Hirsch's index, the $h(a, b)$ index, where $h(a, b)$ is defined as the researcher as at least $h$ papers with $a h^{b}$ citations. He suggest $h(5,2)$ as particularly useful, although he analyzes senior researchers at only the top programs (who are typically highly cited and have published many papers), using Google Scholar citation counts (which are much higher than wOS counts). We find that the $h(5,2)$ index does a poorer job than the $\mathrm{h}$ index of describing scholarly influence of researchers across the entire spectrum of economics graduate programs.

\section{Coauthorship}

A frequent question that arises in this literature is how to treat coauthored papers. Two obvious solutions are (1) to ignore coauthors completely, giving each coauthor full credit for each paper or citation, or (2) to divide the number of citations (or the number of articles) by the number of coauthors. An intermediate approach, suggested by Ellison (2010) and others is to weight each citation or publication by $1 / \mathrm{N}^{c}$, where $\mathrm{c}$ is some number between 0 and 1,0 and 1 representing the extremes just mentioned. Potentially, $\mathrm{c}$ is a parameter that could be estimated. We explore this in some of our specifications below. For the $\mathrm{h}$ index, Ellison adopts a fractional counting method suggested by Egghe (2008). We, too, adopt this suggestion in our analysis.

\section{E. Summary Statistics}

Table 4 presents summary statistics for the data we use in our analysis. Salaries range from $\$ 60,000$ to $\$ 342,000$, with a mean of about $\$ 122,000$. The average professor in our sample has about 20 years of experience and about 16 years of seniority at his or her current institution. He or she has written on average about 21 paper that have received 275 cumulative citations. This falls to 172 in terms of citations per author, reflecting the fact that coauthorship is common in our sample. The Hirsch 
index (h) varies from 0 to 31, with a mean of 6 . Of the 21 articles that the average professor in our sample has published, 2.63 reside in the best journals, 7.05 reside in the second tier, and 11.4 reside in lesser journals (or in journals outside of the economics field). ${ }^{4}$

Table 5 presents more detail about the distributions of our citations variables. The median professor has an h-index of 5. This falls to 4 when adjusted for coauthorship. An $\mathrm{h}$ value of 10 puts an author in the upper quartile. A value of 20 places him or her among the elite.

The $h(5,2)$ index suggested by Hirsch varies little in our sample- 55 percent have a value of 0 or 1 , so it will be difficult to explain variations in salaries in this sample using that variant of the Hirsh index.

As expected, the cumulative citations distribution is highly skewed, with a mean of 275 and a median of 76. A professor with 300 citations is near the $75^{\text {th }}$ percentile. Someone with 1000 cumulative citations is close to the $95^{\text {th }}$ percentile. The highest ranked professor has over 10,000 cumulative citations through 2006.

\section{Results-Salaries}

Table 6a summarizes results of our regression analyses of faculty salaries. A surprising result is that the $\mathrm{h}$ index (and its square) alone explain more than 52 percent of the variation in log salary in our sample, as shown in column 1 . The $\mathrm{h}$ index increases with the length of career, both because the number of articles cited may increase, and also because existing articles acquire more citations. The marginal effect of $h$ decreases as $h$ increases, becoming negative for $h$ values greater than 22 to 32 , depending on the specification.

Column 2 adds basic demographic variables to the model. These explain a small fraction of the residual unexplained variance, but are statistically important. Salaries grow modestly with experience,

\footnotetext{
${ }^{4}$ We adopt the journal tiers of Scott and Mitias (1996). The elite journals are American Economic Review, Econometrica, Journal of Political Economy, Quarterly Journal of Economics, and Review of Economics and Statistics. Another 31 economics journals comprise the "excellent" group here.
} 
even after controlling for citations. Individuals who have not changed employers during their careers have much lower salaries than those who have moved. This result was first emphasized in Ransom (1993) and has been studied (and reconfirmed) in numerous subsequent articles, including Bratsberg, Ragan and Warren (2010), Bratsberg, Ragan and Warren (2003), Monks and Robinson (2001), Barbezat and Donihue (1998), and Moore, Newman and Turnbull (1998). There is no statistically significant difference in pay between men and women in our sample after controlling for the value of $h$.

Column 3 includes publication counts. Even after measuring the impact of publications, the number of publications has some impact on salaries, at least when the articles are published in the best journals. Ten "elite" publications would add about 12 percent to an individual's salary, on top of the rewards for the citations to those and other articles.

In an effort to control for potential cost-of-living and institution-specific differences in salary formation, columns 4 and 5 add state and school fixed-effects. Adding these controls increases the explanatory power of our estimates by roughly 20 percent, enabling us to explain roughly two-thirds of the total variation in salaries. Even with these controls, the h-index remains a very important predictor of current annual salary, with the marginal effect of a one-unit increase from 5 to 6 being 3.94 percent.

Table $6 \mathrm{~b}$ repeats the previous analysis using $\log ($ cumulative citations +1 ) rather than the $h$-index as the explanatory variable. The results are qualitatively similar. However, the $\mathrm{h}$ index fits the data better.

Tables $7 \mathrm{a}$ and $7 \mathrm{~b}$ repeat the prior analysis using citation measures that have been adjusted for coauthorship. An author receives $1 / \mathrm{N}$ citations for each citation to a paper with $\mathrm{N}$ authors. For computing the $\mathrm{h}$ index, this corresponds to Egghe's (2008) "fractional citation counts" method. Again, the results are qualitatively similar.

For both the $\mathrm{h}$ index (Tables $6 a$ and $7 \mathrm{a}$ ) and the log citations (Tables $6 \mathrm{~b}$ and $7 \mathrm{~b}$ ), the unadjusted citations variables have more explanatory power. Is this difference in fit statistically significant? One 
way to approach this question is to consider a more general model, where each citation is adjusted by $1 / N^{c}$. That is, the citation to a paper with two authors would be counted as $1 / 2^{c}$, where $c$ is some number between 0 and 1 . If $c=0$, our results are those in Table 6 . If $c=1$, our results are those in Table 7 . We could imagine estimating $\mathrm{c}$ from our data. This turns out to be a very cumbersome enterprise, especially for the h-index. However, imagine that we did such estimation using a maximum likelihood approach. We could then test whether coauthored papers were fully discounted using a likelihood ratio test, by comparing the values of the log likelihood from the results in Tables $7 \mathrm{a}$ and $7 \mathrm{~b}$ with the maximized log likelihood value. A conservative version of this test, then, is to compare the log likelihood values that we get from our estimates in Tables $6 a$ and $6 b$, which will be less than or equal to the log likelihood for the maximizing value of $c$. Table 8a presents the result of this comparison for the $h$ index. Compared to a chi-squared with one degree of freedom, this "test statistic" is very large, which would lead us to reject to hypothesis of full discounting of citations to coauthored articles.

The same exercise for the log citations variable is presented in Table 8b, with a wider variety of values for c. In this case, it is clear that the value of the likelihood function is decreasing as c increases, and that the best estimate is a value of 0 , as in the previous case. The differences in the log likelihood function are statistically large. Our salary data are best described by the hypothesis that coauthored papers receive the same weight as single-authored papers. We can certainly reject the hypothesis of full discounting.

\section{Results-Departmental Rank}

The prestige of an economics department depends to a large extent (perhaps only) on the reputation of its faculty members. This is apparent in Figure 1, which is a box/whisker plot showing the distribution of $\log ($ cumulative citations +1 ) for faculty in each department in our sample, arrayed according to the 1995 National Research Council rankings of the departments. (This plot shows only 
faculty members whose PhD degree was earned before 1999, as most young faculty members have not had a chance to accumulate many citations.) The distributions shown in this figure presumably reflect the standards that each of these departments has with respect to hiring and granting tenure. Figure 2 shows the distribution of salaries for the faculty included in figure 1, also arrayed by NRC rankings.

One way that publishing important articles can influence a professor's career is by creating opportunities for him or her to work at a more prestigious school. We explore this question by examining the rank of hiring department for all those in our sample who were hired during the period 1993-2006. We restrict our analysis to those hired after 1993 because we want to avoid any influence the professor's own publication record may have had on the 1995 rankings. The results of this analysis are found in Tables 9 and 10-Table 9 reports the results for citation variables that have not been adjusted for coauthorship, while Table 10 reports results for citation variables that have been fully adjusted for coauthorship. The results are not surprising. High $\mathrm{h}$ indexes are associated with appointments at more prestigious (lower rank) departments. The marginal effect of a higher $\mathrm{h}$ index is decreasing, however, as we saw in the salary regressions. We have included date of PhD to allow time for mobility - it may take time for a productive researcher to move to a better department. However, the net effect we observe is that newer PhDs are appointed to better departments, holding constant the $\mathrm{h}$ index or log total citations. There is essentially no gender difference in placement after controlling for other factors. Elite publications help, lesser publications either do not matter (in the case of "excellent articles," or they hurt (in the case of "other" articles).

Our analysis of coauthorship in the case of department rank is quite different than what we found for salaries. Using the same arguments that we used there, it is clear that per capita citations provide a much better fit for the model, and we can clearly reject statistically that coauthored are treated the same as single-authored papers. 


\section{Conclusions}

Influential publications are highly rewarded in academic economics. Both in terms of where an individual works and how much salary he or she earns, the influence of the individual's publications (as measured by citations) is a dominant factor. In fact, the Hirsch index alone explains more than 50 percent of the variation in log salaries for our sample. In terms of salary, larger numbers of publications increase salary, even after counting citations, but it is only articles in the elite journals that have an impact on pay. Surprisingly, it appears that sharing fame is costless-a model in which an author gets full credit for citations to coauthored publications fits the data much better than per capita citation counts.

With respect to salary, we find significant rewards for changing institutions during one's career. This phenomenon has been frequently noted in other studies, but our analysis provides the most convincing evidence to date that the effect is not due to the selective mobility of the most productive researchers.

The prestige of the department at which established researchers are appointed is also strongly related to an individual's citations history. However, in contrast to the case of salaries, for explaining the rank of an individual's departmental per capita citations provide a much better fit. This suggests that the institutions that determine salary are somewhat different than those that determine mobility across different institutions. 


\section{References}

Barbezat, D. A. and M. R. Donihue (1998). "Do faculty salaries rise with job seniority?" Economics Letters 58(2): 239-244.

Black, D. A. and M. A. Loewenstein (1991). Self-Enforcing Labor Contracts with Costly Mobility. Research in Labor Economics. R. G. Ehrenberg. London, JAI Press. 12.

Bratsberg, B., J. F. Ragan, et al. (2003). "Negative returns to seniority: New evidence in academic markets." Industrial \& Labor Relations Review 56(2): 306-323.

Bratsberg, B., J. F. Ragan, Jr., et al. (2010). "Does Raiding Explain the Negative Returns to Faculty Seniority?" Economic Inquiry 48(3): 704-721.

Cole, J. (2000). A Short History of the Use of Citations as a Measure of the Impact of Scientific and Scholarly Work. The Web of Knowledge: A Festschrift in Honor of Eugene Garfield. B. Cronin and H. B. Atkins. Medford, NJ, Information Today, Inc.

Diamond, A. M., Jr. (1986). "What is a Citation Worth?" The Journal of Human Resources 21(2): 200-215.

Egghe, L. (2008). "Mathematical Theory of the h- and g-Index in Case of Fractional Counting of Authorship." Journal of the American Society for Information Science and Technology 59(10): 16081616.

Ellison, G. (2010). How Does the Market use Citation Data? The Hirsch Index in Economics. NBER Working Paper \#16419. Cambridge, Massachusetts, National Bureau of Economic Research.

Garfield, E. (1990). "How ISI Selectes Journals for Coverage: Quantitative and Qualitative Considerations." Essays of an Information Scientist 13(22): 185-193.

Hamermesh, D. S., G. E. Johnson, et al. (1982). "Scholarship, Citations and Salaries: Economic Rewards in Economics." Southern Economic Journal 49(2): 472-481.

Hamermesh, D. S. and G. A. Pfann (2011). "Reputation and Earnings: The Roles of Quality and Quantity in Academe." Economic Inquiry.

Hilmer, M. J. and C. E. Hilmer (2011). "Negative Returns to Seniority and Job Mobility across the Program Quality Distribution: Are Top Public PhD-Granting Programs Different?" American Economic Review 101(3): 466-470.

Hirsch, J. E. (2005). "An Index to Quantify an Individual's Scientific Research Output." Proccedings of the National Academy of Science 102(46): 16569-16572.

Holtmann, A. G. and A. E. Bayer (1970). "Determinants of Professional Income Among Recent Recipients of Natural Science Doctorates." Journal of Business 43(4): 410-418.

Katz, D. (1973). "Faculty Salaries, Promotions and Productivity at a Large University." The American Economic Review 63(3): 469-477. 
Klein, D. B. and E. Chiang (2004). "The Social Science Citation Index: A Black Box--With and Ideological Bias?" Eon Journal Watch 1(1): 134-165.

Monks, J. and M. Robinson (2001). "The returns to seniority in academic labor markets." Journal of Labor Research 22(2): 415-427.

Moore, W. J., R. J. Newman, et al. (1998). "Do academic salaries decline with seniority?" Journal of Labor Economics 16(2): 352-366.

Moore, W. J., R. J. Newman, et al. (2001). "Reputational Capital and Academic Pay." Economic Inquiry 39(4): 663-671.

Posner, R. A. (2000). "An Economics Analysis of the Use of Citations in the Law." American Law and Economics Review 2(2): 381-406.

Ransom, M. R. (1993). "Seniority and Monopsony in the Academic Labor Market." The American Economic Review 83(1): 221-233.

Sauer, R. D. (1988). "Estimates of the Returns to Quality and Coauthorship in Economic Academia." Journal of Political Economy 96(4): 855-866.

Scott, L. C. and P. M. Mitias (1996). "Trends in Rankings of Economics Departments in the U. S.: An Update." Economic Inquiry 34(2): 378-400.

Siegfried, J. J. and K. J. White (1973). "Financial Reward to Research and Teaching: A Case Study of Academic Economists." The American Economic Review 63(2): 309-315.

Tuckman, H. P., J. H. Gapinski, et al. (1977). "Faculty Skills and the Salary Structure in Academe: A Market Perspective." The American Economic Review 67(4): 692-702.

Tuckman, H. P. and J. Leahey (1975). "What is an Article Worth?" Journal of Political Economy 83(5): 951-968. 
Table 1

Economics PhD Programs in our Sample

\begin{tabular}{|c|c|c|c|}
\hline $\begin{array}{l}1995 \\
\text { NRC Rank }\end{array}$ & Program & $\begin{array}{l}1995 \\
\text { NRC Rank }\end{array}$ & Program \\
\hline $\begin{array}{c}7 \\
11 \\
16 \\
20 \\
24 \\
25 \\
26 \\
27 \\
28 \\
30 \\
31 \\
33 \\
35 \\
36 \\
37 \\
38 \\
41 \\
42 \\
44 \\
49 \\
50 \\
51 \\
57 \\
58 \\
62 \\
63 \\
64\end{array}$ & $\begin{array}{l}\text { UC Berkeley } \\
\text { UCLA } \\
\text { UCSD } \\
\text { Maryland } \\
\text { Virginia } \\
\text { UNC Chapel Hill } \\
\text { UW Seattle } \\
\text { Michigan State } \\
\text { Illinois } \\
\text { lowa } \\
\text { UT Austin } \\
\text { Texas A\&M } \\
\text { Ohio State } \\
\text { lowa State } \\
\text { Arizona } \\
\text { UC Davis } \\
\text { Florida } \\
\text { NC State } \\
\text { Indiana } \\
\text { UC Santa Barbara } \\
\text { Purdue } \\
\text { Massachusetts } \\
\text { Houston } \\
\text { SUNY Buffalo } \\
\text { Florida State } \\
\text { Georgia } \\
\text { Kentucky }\end{array}$ & $\begin{array}{l}13 \\
15 \\
65 \\
66 \\
67 \\
69 \\
71 \\
73 \\
74 \\
75 \\
76 \\
77 \\
78 \\
83 \\
84 \\
86 \\
87 \\
90 \\
92 \\
93 \\
97 \\
98 \\
100 \\
101 \\
103 \\
104\end{array}$ & $\begin{array}{l}\text { Michigan } \\
\text { Wisconsin } \\
\text { South Carolina } \\
\text { SUNY Binghamton } \\
\text { Arizona State } \\
\text { Georgia State } \\
\text { UC Riverside } \\
\text { Kansas } \\
\text { Auburn } \\
\text { Clemson } \\
\text { Wyoming } \\
\text { Southern Illinois } \\
\text { SUNY Albany } \\
\text { Washington State } \\
\text { Connecticut } \\
\text { Oklahoma State } \\
\text { Nebraska } \\
\text { Utah } \\
\text { West Virginia } \\
\text { Missouri } \\
\text { Cincinnati } \\
\text { UT Dallas } \\
\text { Colorado State } \\
\text { New Hampshire } \\
\text { Colorado School of Mines } \\
\text { Utah State }\end{array}$ \\
\hline
\end{tabular}


Table 2

Summary Statistics for Unique Articles

$(\mathrm{N}=19,937)$

Mean Standard

Total Number of Citations

Average Number of Citations per Year

Publication Year

Number of Authors

Deviation

Decade of Publication
1950s
$1960 s$
$1970 s$
$1980 s$
$1990 s$
$2000 s$

$\begin{array}{rrrr}12.84 & 53.184 & 0 & 4256 \\ 0.89 & 2.640 & 0 & 157.63 \\ 1991.75 & 9.846 & 1956 & 2006 \\ 1.80 & 0.975 & 1 & 16\end{array}$

0.002

0.017

0.041

0

1

0.107

0.128

0

1

0.260

0.309

0.347

0.439

0

1

0.267

0.476

0.443

0

0

1

1

1

1 
Table 3

Summary Statistics for Unique Articles:

Distribution by Citation Frequency

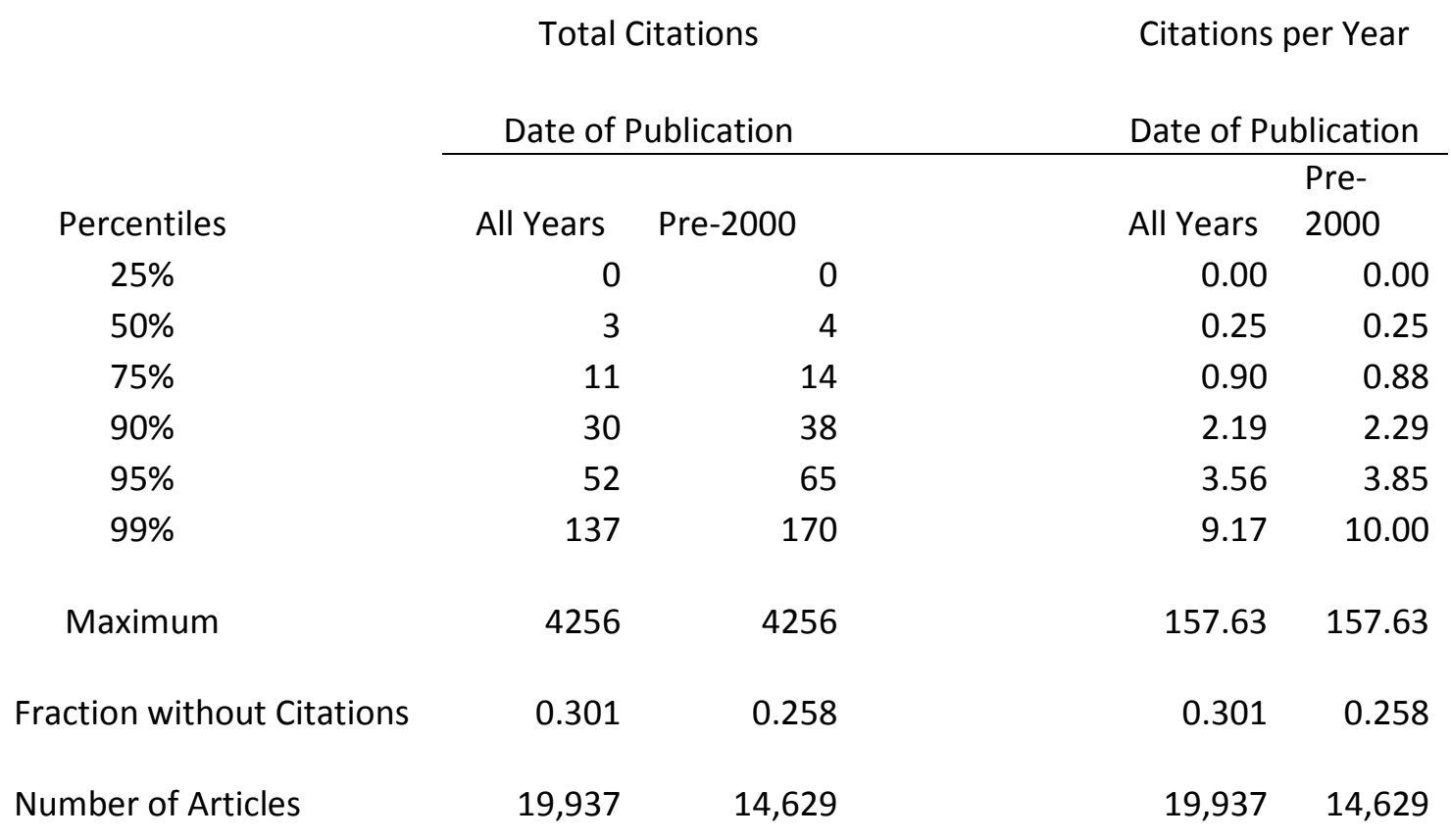


Table 4

Summary Statistics for Analysis Variables

$(\mathrm{N}=1,009)$

Variable
Salary
Log( Salary)
Years Experience
Years Seniority
Year PhD granted
Total Number of Articles
Number of Articles in Elite Journals
Number of Articles in Excellent Journals
Number of Other Articles
Cumulative Citations
Cumulative Citations Per Author
Log(Cum Citations +1$)$
Log(Cum Citations per Author +1$)$
h (Hirsch index)
$H_{p}$ (per author adjusted)
Citations to most cited paper
Citations to $2^{\text {nd }}$ most cited paper
Sum citations to 4 most cited papers
Citations per author (most cited)
Citations per author ( $2^{\text {nd }}$ most cited)
Sum citations per author ( 4 most cited)

Mean

Std. Dev. Min Max

$\begin{array}{rrrr}121,674.90 & 46,132.03 & 60,000.00 & 342,141.90 \\ 11.64919 & 0.3339894 & 11.0021 & 12.74 \\ 19.95 & 12.17 & 0 & 58.00 \\ 15.64 & 11.54 & 0 & 50.00 \\ 1986.91 & 12.08 & 1950 & 2007 \\ 21.04 & 24.10 & 0 & 234 \\ 2.63 & 3.93 & 0 & 33 \\ 7.05 & 8.75 & 0 & 99 \\ 11.37 & 16.70 & 0 & 208 \\ 274.99 & 581.86 & 0 & 10,943.00 \\ 171.68 & 389.07 & 0 & 7,958.92 \\ 4.00 & 2.23 & 0 & 9.30 \\ 3.59 & 2.11 & 0 & 8.98 \\ 6.03 & 5.34 & 0 & 31.00 \\ 4.73 & 4.29 & 0 & 25.00 \\ 70.34 & 189.25 & 0 & 4,256.00 \\ 38.50 & 108.33 & 0 & 2,785.00 \\ 153.21 & 363.68 & 0 & 8,372.00 \\ 47.57 & 162.87 & 0 & 4,256.00 \\ 23.57 & 50.90 & 0 & 991.00 \\ 99.51 & 261.21 & 0 & 6,388.33\end{array}$


Table 5

Quantiles of Hirsch Related Indexes and Cumulative Citations

\begin{tabular}{|c|c|c|c|c|c|}
\hline Percentile & $\mathrm{h}$ & $h(5,2)$ & $\mathrm{h}$ (per author) & $\begin{array}{l}\text { Cumulative } \\
\text { Citations }\end{array}$ & $\begin{array}{c}\text { Cumulative } \\
\text { Citations/Author }\end{array}$ \\
\hline $10 \%$ & 0 & 0 & 0 & 0 & 0 \\
\hline $25 \%$ & 2 & 1 & 1 & 12 & 6.83 \\
\hline $50 \%$ & 5 & 1 & 4 & 76 & 50.67 \\
\hline $75 \%$ & 9 & 2 & 7 & 302 & 184.50 \\
\hline $90 \%$ & 14 & 3 & 11 & 749 & 457.92 \\
\hline $95 \%$ & 17 & 3 & 14 & 1179 & 730.50 \\
\hline $99 \%$ & 24 & 4 & 19 & 2321 & 1391 \\
\hline Mean & 6.03 & 1.43 & 4.73 & 274.99 & 171.68 \\
\hline Std. Deviation & 5.34 & 1.12 & 4.29 & 581.86 & 389.07 \\
\hline Maximum & 31 & 6 & 25 & 10943 & 7958.92 \\
\hline
\end{tabular}


Table 6a

Regression Results-Salaries (without co-authorship adjustment)

$(\mathrm{N}=1,009)$

Model

\begin{tabular}{|c|c|c|c|c|c|}
\hline Variable & (1) & $(2)$ & (3) & (4) & (5) \\
\hline h & $\begin{array}{c}0.0776 * * * \\
(.00441)\end{array}$ & $\begin{array}{c}0.0856 * * * \\
(.00587)\end{array}$ & $\begin{array}{c}0.0735^{* * *} \\
(.00734)\end{array}$ & $\begin{array}{c}0.0583 * * * \\
(.00534)\end{array}$ & $\begin{array}{c}0.0516 * * * \\
(.00532)\end{array}$ \\
\hline$h^{2}$ & $\begin{array}{c}-0.00153^{* * *} \\
(.000274)\end{array}$ & $\begin{array}{c}-0.00201 * * * \\
(.000311)\end{array}$ & $\begin{array}{c}-0.00203 * * * \\
(.000415)\end{array}$ & $\begin{array}{c}-0.00140 * * * \\
(.000230)\end{array}$ & $\begin{array}{c}-0.00122 * * * \\
(.000235)\end{array}$ \\
\hline Experience & & $\begin{array}{c}0.0122 * * * \\
(.00349)\end{array}$ & $\begin{array}{c}0.0136^{* * *} \\
(.00401)\end{array}$ & $\begin{array}{c}0.0130 * * \\
(.00395)\end{array}$ & $\begin{array}{c}0.0168 * * * \\
(.00368)\end{array}$ \\
\hline Experience $^{2}$ & & $\begin{array}{c}-0.000144^{*} \\
(.00007)\end{array}$ & $\begin{array}{c}-0.000215^{*} \\
(.00009)\end{array}$ & $\begin{array}{l}-0.000197 * \\
(.0000839)\end{array}$ & $\begin{array}{c}-0.000255^{* * *} \\
(.0000754)\end{array}$ \\
\hline Seniority & & $\begin{array}{c}-0.0238 * * * \\
(.00316)\end{array}$ & $\begin{array}{c}-0.0220 * * * \\
(.00361)\end{array}$ & $\begin{array}{c}-0.0204 * * * \\
(.00345)\end{array}$ & $\begin{array}{c}-0.0209 * * * \\
(.00330)\end{array}$ \\
\hline Seniority ${ }^{2}$ & & $\begin{array}{c}0.000371^{* * *} \\
(.0000762)\end{array}$ & $\begin{array}{c}0.000350 * * * \\
(.0000880)\end{array}$ & $\begin{array}{c}0.000333 * * * \\
(.0000822)\end{array}$ & $\begin{array}{c}0.000343^{* * *} \\
(.0000763)\end{array}$ \\
\hline Male & & $\begin{array}{c}0.0145 \\
(.02120)\end{array}$ & $\begin{array}{l}0.00898 \\
(.01800)\end{array}$ & $\begin{array}{c}0.0256 \\
(.01760)\end{array}$ & $\begin{array}{c}0.0212 \\
(.01570)\end{array}$ \\
\hline \# Elite Articles & & & $\begin{array}{l}0.0121 * * \\
(.00375)\end{array}$ & $\begin{array}{l}0.00870 * \\
(.00369)\end{array}$ & $\begin{array}{l}0.00551 \\
(.00346)\end{array}$ \\
\hline \# Excellent Articles & & & $\begin{array}{l}0.00225 \\
(.00157)\end{array}$ & $\begin{array}{c}0.00298 * \\
(.00134)\end{array}$ & $\begin{array}{l}0.00325 * \\
(.00131)\end{array}$ \\
\hline \# Other Articles & & & $\begin{array}{l}0.00109 \\
(.00065)\end{array}$ & $\begin{array}{c}0.00101 \\
(.000654)\end{array}$ & $\begin{array}{l}0.00136 * \\
(.000664)\end{array}$ \\
\hline Constant & $\begin{array}{c}11.34^{* * *} \\
(.0136)\end{array}$ & $\begin{array}{c}11.38 * * * \\
(.0242)\end{array}$ & $\begin{array}{c}11.37^{* * *} \\
(.0195)\end{array}$ & $\begin{array}{c}11.29 * * * \\
(.0637)\end{array}$ & $\begin{array}{c}11.43^{* * *} \\
(.0537)\end{array}$ \\
\hline$R^{2}$ & 0.524 & 0.568 & 0.577 & 0.642 & 0.689 \\
\hline Includes State Fixed Effects & & & & $x$ & \\
\hline Includes School Fixed Effects & & & & & $x$ \\
\hline
\end{tabular}


Table $6 \mathrm{~b}$

Regression Results - Salaries (without co-authorship adjustment)

$(\mathrm{N}=1,009)$

Model

\begin{tabular}{|c|c|c|c|c|c|}
\hline Variable & $(1)$ & $(2)$ & (3) & $(4)$ & $(5)$ \\
\hline Log (Cum Cites+1) & $\begin{array}{l}-0.0204 * \\
(.00980)\end{array}$ & $\begin{array}{l}0.00785 \\
(.01240)\end{array}$ & $\begin{array}{c}0.0168 \\
(.01270)\end{array}$ & $\begin{array}{c}0.0197 \\
(.01230)\end{array}$ & $\begin{array}{c}0.0155 \\
(.01160)\end{array}$ \\
\hline Log $(\text { Cum Cites }+1)^{2}$ & $\begin{array}{l}0.0173 * * * \\
(.001500)\end{array}$ & $\begin{array}{c}0.0142 * * * \\
(.001590)\end{array}$ & $\begin{array}{c}0.0101 * * * \\
(.001950)\end{array}$ & $\begin{array}{c}0.00792 * * * \\
(.001900)\end{array}$ & $\begin{array}{c}0.00725 * * * \\
(.001820)\end{array}$ \\
\hline Experience & & $\begin{array}{l}0.0111^{* *} \\
(.00414)\end{array}$ & $\begin{array}{l}0.0123 * * \\
(.00440)\end{array}$ & $\begin{array}{c}0.0148 * * * \\
(.00431)\end{array}$ & $\begin{array}{c}0.0187^{* * *} \\
(.00403)\end{array}$ \\
\hline Experience $^{2}$ & & $\begin{array}{c}-0.000125 \\
(.00009)\end{array}$ & $\begin{array}{c}-0.000195^{*} \\
(.00009)\end{array}$ & $\begin{array}{c}-0.000233^{* *} \\
(.0000902)\end{array}$ & $\begin{array}{c}-0.000294^{* * *} \\
(.0000823)\end{array}$ \\
\hline Seniority & & $\begin{array}{c}-0.0243 * * * \\
(.00336)\end{array}$ & $\begin{array}{c}-0.0229 * * * \\
(.00351)\end{array}$ & $\begin{array}{c}-0.0210 * * * \\
(.00343)\end{array}$ & $\begin{array}{c}-0.0215^{* * *} \\
(.00329)\end{array}$ \\
\hline Seniority $^{2}$ & & $\begin{array}{c}0.000388 * * * \\
(.0000808)\end{array}$ & $\begin{array}{c}0.000381^{* * *} \\
(.0000853)\end{array}$ & $\begin{array}{c}0.000347^{* * *} \\
(.0000818)\end{array}$ & $\begin{array}{c}0.000358 * * * \\
(.0000765)\end{array}$ \\
\hline Male & & $\begin{array}{c}0.0139 \\
(.01810)\end{array}$ & $\begin{array}{l}0.00966 \\
(.01800)\end{array}$ & $\begin{array}{c}0.0258 \\
(.01760)\end{array}$ & $\begin{array}{c}0.0201 \\
(.01570)\end{array}$ \\
\hline \# Elite Articles & & & $\begin{array}{c}0.00993 * * \\
(.00355)\end{array}$ & $\begin{array}{l}0.00747 * \\
(.00356)\end{array}$ & $\begin{array}{l}0.00453 \\
(.00332)\end{array}$ \\
\hline \# Excellent Articles & & & $\begin{array}{l}0.00255 \\
(.00160)\end{array}$ & $\begin{array}{c}0.00365^{* *} \\
(.00141)\end{array}$ & $\begin{array}{l}0.00393 * * \\
(.00138)\end{array}$ \\
\hline \# Other Articles & & & $\begin{array}{l}0.00123 \\
(.00066)\end{array}$ & $\begin{array}{l}0.00143 * \\
(.000666)\end{array}$ & $\begin{array}{l}0.00178 * * \\
(.000680)\end{array}$ \\
\hline Constant & $\begin{array}{c}11.37 * * * \\
(.0120)\end{array}$ & $\begin{array}{c}11.39 * * * \\
(.0189)\end{array}$ & $\begin{array}{l}11.38^{* * *} \\
(.0196)\end{array}$ & $\begin{array}{l}11.30 * * * \\
(.0679)\end{array}$ & $\begin{array}{l}11.42 * * * \\
(.0536)\end{array}$ \\
\hline$R^{2}$ & 0.517 & 0.561 & 0.572 & 0.635 & 0.683 \\
\hline Includes State Fixed Effects & & & & $x$ & \\
\hline Includes School Fixed Effects & & & & & $x$ \\
\hline
\end{tabular}


Table 7a

Regression Results-Salaries (with co-authorship adjustment)

$(\mathrm{N}=1,009)$

Model

\begin{tabular}{|c|c|c|c|c|c|}
\hline Variable & $(1)$ & $(2)$ & (3) & $(4)$ & $(5)$ \\
\hline h (per author) & $\begin{array}{c}0.0776 * * * \\
(.00438)\end{array}$ & $\begin{array}{c}0.0856 * * * \\
(.00664)\end{array}$ & $\begin{array}{c}0.0735^{* * *} \\
(.00734)\end{array}$ & $\begin{array}{c}0.0639 * * * \\
(.00731)\end{array}$ & $\begin{array}{c}0.0562 * * * \\
(.00711)\end{array}$ \\
\hline $\mathrm{h}^{2}$ (per author) & $\begin{array}{c}-0.00153 * * * \\
(.000306)\end{array}$ & $\begin{array}{c}-0.00201 * * * \\
(.000389)\end{array}$ & $\begin{array}{c}-0.00203 * * * \\
(.000415)\end{array}$ & $\begin{array}{c}-0.00190 * * * \\
(.000423)\end{array}$ & $\begin{array}{c}-0.00166 * * * \\
(.000409)\end{array}$ \\
\hline Experience & & $\begin{array}{c}0.0122 * * * \\
(.00382)\end{array}$ & $\begin{array}{c}0.0136^{* * *} \\
(.00401)\end{array}$ & $\begin{array}{c}0.0164 * * * \\
(.00398)\end{array}$ & $\begin{array}{l}0.0199 * * * \\
(.00372)\end{array}$ \\
\hline Experience $^{2}$ & & $\begin{array}{c}-0.000144 * \\
(.00008)\end{array}$ & $\begin{array}{c}-0.000215^{*} \\
(.00009)\end{array}$ & $\begin{array}{c}-0.000259 * * \\
(.0000840)\end{array}$ & $\begin{array}{c}-0.000310 * * * \\
(.0000754)\end{array}$ \\
\hline Seniority & & $\begin{array}{c}-0.0238 * * * \\
(.00350)\end{array}$ & $\begin{array}{c}-0.0220 * * * \\
(.00361)\end{array}$ & $\begin{array}{c}-0.0203 * * * \\
(.00352)\end{array}$ & $\begin{array}{l}-0.0207^{* * *} \\
(.00337)\end{array}$ \\
\hline Seniority ${ }^{2}$ & & $\begin{array}{c}0.000371^{* * *} \\
(.0000839)\end{array}$ & $\begin{array}{c}0.000350 * * * \\
(.0000880)\end{array}$ & $\begin{array}{c}0.000318 * * * \\
(.0000838)\end{array}$ & $\begin{array}{c}0.000329 * * * \\
(.0000777)\end{array}$ \\
\hline Male & & $\begin{array}{c}0.0145 \\
(.01840)\end{array}$ & $\begin{array}{l}0.00898 \\
(.01800)\end{array}$ & $\begin{array}{c}0.0238 \\
(.01750)\end{array}$ & $\begin{array}{c}0.0191 \\
(.01570)\end{array}$ \\
\hline \# Elite Articles & & & $\begin{array}{c}0.0121^{* *} \\
(.00375)\end{array}$ & $\begin{array}{c}0.00996 * * \\
(.00379)\end{array}$ & $\begin{array}{l}0.00678 \\
(.00355)\end{array}$ \\
\hline \# Excellent Articles & & & $\begin{array}{l}0.00225 \\
(.00157)\end{array}$ & $\begin{array}{l}0.00340 * \\
(.00141)\end{array}$ & $\begin{array}{c}0.00372 * * \\
(.00138)\end{array}$ \\
\hline \# Other Articles & & & $\begin{array}{l}0.00109 \\
(.00065)\end{array}$ & $\begin{array}{c}0.00134 * \\
(.000672)\end{array}$ & $\begin{array}{c}0.00165^{*} \\
(.000681)\end{array}$ \\
\hline Constant & $\begin{array}{c}11.34 * * * \\
(.0106)\end{array}$ & $\begin{array}{c}11.38 * * * \\
(.0191)\end{array}$ & $\begin{array}{c}11.37 * * * \\
(.0195)\end{array}$ & $\begin{array}{c}11.32 * * * \\
(.0607)\end{array}$ & $\begin{array}{c}11.42^{* * *} \\
(.0548)\end{array}$ \\
\hline $\mathrm{R}^{2}$ & 0.512 & 0.557 & 0.568 & 0.633 & 0.681 \\
\hline Includes State Fixed Effects & & & & $x$ & \\
\hline Includes School Fixed Effects & & & & & $x$ \\
\hline
\end{tabular}


Table 7b

Regression Results-Salaries (with co-authorship adjustment)

$(\mathrm{N}=1,009)$

Model

\begin{tabular}{|c|c|c|c|c|c|}
\hline Variable & $(1)$ & $(2)$ & (3) & $(4)$ & $(5)$ \\
\hline \multirow[t]{2}{*}{ Log (Cum Cites*+1) } & -0.00228 & $0.0280 *$ & $0.0356 *$ & $0.0367 * *$ & $0.0310^{*}$ \\
\hline & $(.01060)$ & $(.01400)$ & $(.01420)$ & $(.01380)$ & $(.01310)$ \\
\hline \multirow[t]{2}{*}{ Log $(\text { Cum Cites* }+1)^{2}$} & $0.0168 * * *$ & $0.0133 * * *$ & $0.00854 * * *$ & $0.00616 * *$ & $0.00544 * *$ \\
\hline & $(.001730)$ & $(.001870)$ & $(.002210)$ & $(.002170)$ & $(.002060)$ \\
\hline \multirow[t]{2}{*}{ Experience } & & $0.0118 * *$ & $0.0129 * *$ & $0.0156 * * *$ & $0.0196 * * *$ \\
\hline & & $(.00415)$ & $(.00440)$ & $(.00433)$ & $(.00409)$ \\
\hline & & & & & - \\
\hline \multirow[t]{2}{*}{ Experience $^{2}$} & & -0.000143 & $-0.000214^{*}$ & $-0.000253^{* *}$ & $0.000315^{* * *}$ \\
\hline & & $(.00008)$ & $(.00009)$ & $(.0000884)$ & $(.0000818)$ \\
\hline \multirow[t]{2}{*}{ Seniority } & & $-0.0243 * * *$ & $-0.0227 * * *$ & $-0.0208 * * *$ & $-0.0213 * * *$ \\
\hline & & $(.00337)$ & $(.00355)$ & $(.00346)$ & $(.00333)$ \\
\hline \multirow[t]{2}{*}{ Seniority $^{2}$} & & $0.000381^{* * *}$ & $0.000374 * * *$ & $0.000337 * * *$ & $0.000347^{* * *}$ \\
\hline & & $(.0000809)$ & $(.0000858)$ & $(.0000818)$ & $(.0000770)$ \\
\hline \multirow[t]{2}{*}{ Male } & & 0.0153 & 0.0102 & 0.0257 & 0.0198 \\
\hline & & $(.01810)$ & $(.01790)$ & $(.01760)$ & $(.01570)$ \\
\hline \multirow[t]{2}{*}{ \# Elite Articles } & & & $0.0112 * *$ & $0.00901^{*}$ & 0.00614 \\
\hline & & & $(.00361)$ & $(.00361)$ & $(.00338)$ \\
\hline \multirow[t]{2}{*}{ \# Excellent Articles } & & & 0.00272 & $0.00374 *$ & $0.00407 * *$ \\
\hline & & & $(.00165)$ & $(.00146)$ & $(.00144)$ \\
\hline \multirow[t]{2}{*}{ \# Other Articles } & & & $0.00143^{*}$ & $0.00160 *$ & $0.00195^{* *}$ \\
\hline & & & $(.00066)$ & $(.000676)$ & $(.000697)$ \\
\hline \multirow[t]{2}{*}{ Constant } & $11.37^{* * *}$ & $11.38 * * *$ & $11.37 * * *$ & $11.31 * * *$ & $11.42 * * *$ \\
\hline & $(.0119)$ & $(.0189)$ & $(.0196)$ & $(.0653)$ & $(.0539)$ \\
\hline $\mathrm{R}^{2}$ & 0.505 & 0.552 & 0.565 & 0.629 & 0.677 \\
\hline Includes State Fixed Effects & & & & $x$ & \\
\hline Includes School Fixed Effects & & & & & $x$ \\
\hline $\begin{array}{l}\text { Dependent variable is } \ln \text { (Salary). } \\
p<0.001\end{array}$ & Robust stan & errors in pa & neses. P-value & $* \mathrm{p}<0.05, * *$ & $0.01 * * *$ \\
\hline
\end{tabular}


Table 8a

Log Likelihood Values for Different

Models of Coauthorship

C

Log likelihood value

0

109.1088

1

98.6715

"Conservative" LR Test Statistic $=20.87$

\begin{abstract}
Table $8 \mathrm{~b}$
Log Likelihood Values for Different

Models of Coauthorship using Log Cumulative Citations
\end{abstract}

C

Log likelihood

0

102.8831511

.25

102.2588632

.5

100.6923021

.75

98.25933209

1.0

95.10564948

"Conservative" LR test Statistic $=15.555$ 
Table 9

Ordered Probit Regression Model

Dependent variable is 1995 NRC Rank

Citations Variables Not Adjusted for Coauthorship

Model

\begin{tabular}{|c|c|c|c|c|}
\hline Variable & $(1)$ & $(2)$ & (3) & ?]?? \\
\hline h & $\begin{array}{r}-0.232 * * * \\
(0.0432)\end{array}$ & $\begin{array}{r}-0.213^{* * *} \\
(0.0450)\end{array}$ & & \\
\hline$h^{2}$ & $\begin{array}{r}0.00646 * * * \\
(0.00168)\end{array}$ & $\begin{array}{r}0.00528 * * \\
(0.00178)\end{array}$ & & \\
\hline Log (Cum Cites +1) & & & $\begin{array}{l}-0.246 \\
(0.170)\end{array}$ & $\begin{array}{c}-0.302 \\
(0.176)\end{array}$ \\
\hline Log $(\text { Cum Cites }+1)^{2}$ & & & $\begin{array}{r}-0.0149 \\
(0.0206)\end{array}$ & $\begin{array}{r}-0.00594 \\
(0.0225)\end{array}$ \\
\hline Year of PhD & $\begin{array}{r}-0.0475^{* * *} \\
(0.0136)\end{array}$ & $\begin{array}{r}-0.0442 * * \\
(0.0143)\end{array}$ & $\begin{array}{r}-0.0555^{* * *} \\
(0.0140)\end{array}$ & $\begin{array}{r}-0.0442^{* *} \\
(0.0148)\end{array}$ \\
\hline Male & $\begin{array}{r}0.0372 \\
(0.180)\end{array}$ & $\begin{array}{l}0.0795 \\
(0.181)\end{array}$ & $\begin{array}{r}0.00628 \\
(0.180)\end{array}$ & $\begin{array}{l}0.0385 \\
(0.180)\end{array}$ \\
\hline \# Elite articles & & $\begin{array}{r}-0.0972 * * * \\
(0.0253)\end{array}$ & & $\begin{array}{r}-0.0878^{* * *} \\
(0.0260)\end{array}$ \\
\hline \# Excellent articles & & $\begin{array}{r}0.0157 \\
(0.0104)\end{array}$ & & $\begin{array}{r}0.0122 \\
(0.0102)\end{array}$ \\
\hline \# Other articles & & $\begin{array}{r}0.0170 * * * \\
(0.00501)\end{array}$ & & $\begin{array}{r}0.0169 * * * \\
(0.00451)\end{array}$ \\
\hline Log Likelihood & -830.99 & -816.06 & -827.04 & -813.73 \\
\hline$N$ & 232 & 232 & 232 & 232 \\
\hline
\end{tabular}

Standard errors in parentheses. P values: $\mathrm{p}<0.05 * *, \mathrm{p}<0.01, * * * \mathrm{p}<0.001$ 
Table 10

Ordered Probit Regression Model

Dependent variable is 1995 NRC Rank

Citations Variables Adjusted for Coauthorship

Model

\begin{tabular}{|c|c|c|c|c|}
\hline Variable & (1) & $(2)$ & (3) & (4) \\
\hline h (per author) & $\begin{array}{r}-0.289 * * * \\
(0.0569)\end{array}$ & $\begin{array}{r}-0.279 * * * \\
(0.0592)\end{array}$ & & \\
\hline$h^{2}$ (per author) & $\begin{array}{r}0.00905^{* *} \\
(0.00287)\end{array}$ & $\begin{array}{r}0.00849 * * \\
(0.00293)\end{array}$ & & \\
\hline Log (Cum Cites +1) & & & $\begin{array}{r}-0.326 \\
(0.173)\end{array}$ & $\begin{array}{r}-0.378^{*} \\
(0.176)\end{array}$ \\
\hline Log (Cum Cites+1) $)^{2}$ & & & $\begin{array}{r}-0.0107 \\
(0.0225)\end{array}$ & $\begin{array}{r}-0.00172 \\
(0.0241)\end{array}$ \\
\hline Year of PhD & $\begin{array}{r}-0.0537^{* * *} \\
(0.0133)\end{array}$ & $\begin{array}{r}-0.0456 * * \\
(0.0143)\end{array}$ & $\begin{array}{r}-0.0585^{* * *} \\
(0.0139)\end{array}$ & $\begin{array}{r}-0.0471^{* *} \\
(0.0148)\end{array}$ \\
\hline Male & $\begin{array}{l}0.0701 \\
(0.180)\end{array}$ & $\begin{array}{r}0.106 \\
(0.181)\end{array}$ & $\begin{array}{r}-0.00271 \\
(0.180)\end{array}$ & $\begin{array}{l}0.0291 \\
(0.180)\end{array}$ \\
\hline \# Elite articles & & $\begin{array}{r}-0.0919 * * * \\
(0.0252)\end{array}$ & & $\begin{array}{r}-0.0876^{* * *} \\
(0.0257)\end{array}$ \\
\hline \# Excellent articles & & $\begin{array}{r}0.0157 \\
(0.0103)\end{array}$ & & $\begin{array}{r}0.0135 \\
(0.0102)\end{array}$ \\
\hline \# Other articles & & $\begin{array}{r}0.0167 * * * \\
(0.00459)\end{array}$ & & $\begin{array}{r}0.0166^{* * *} \\
(0.00448)\end{array}$ \\
\hline Log Likelihood & -829.01 & -814.72 & -825.04 & -811.81 \\
\hline $\mathrm{N}$ & 232 & 232 & 232 & 232 \\
\hline
\end{tabular}

Standard errors in parentheses. P values: $\mathrm{p}<0.05^{* *}, \mathrm{p}<0.01, * * * \mathrm{p}<0.001$ 
Figure 1: Distribution of log citations by "mature" faculty over NRC Rank

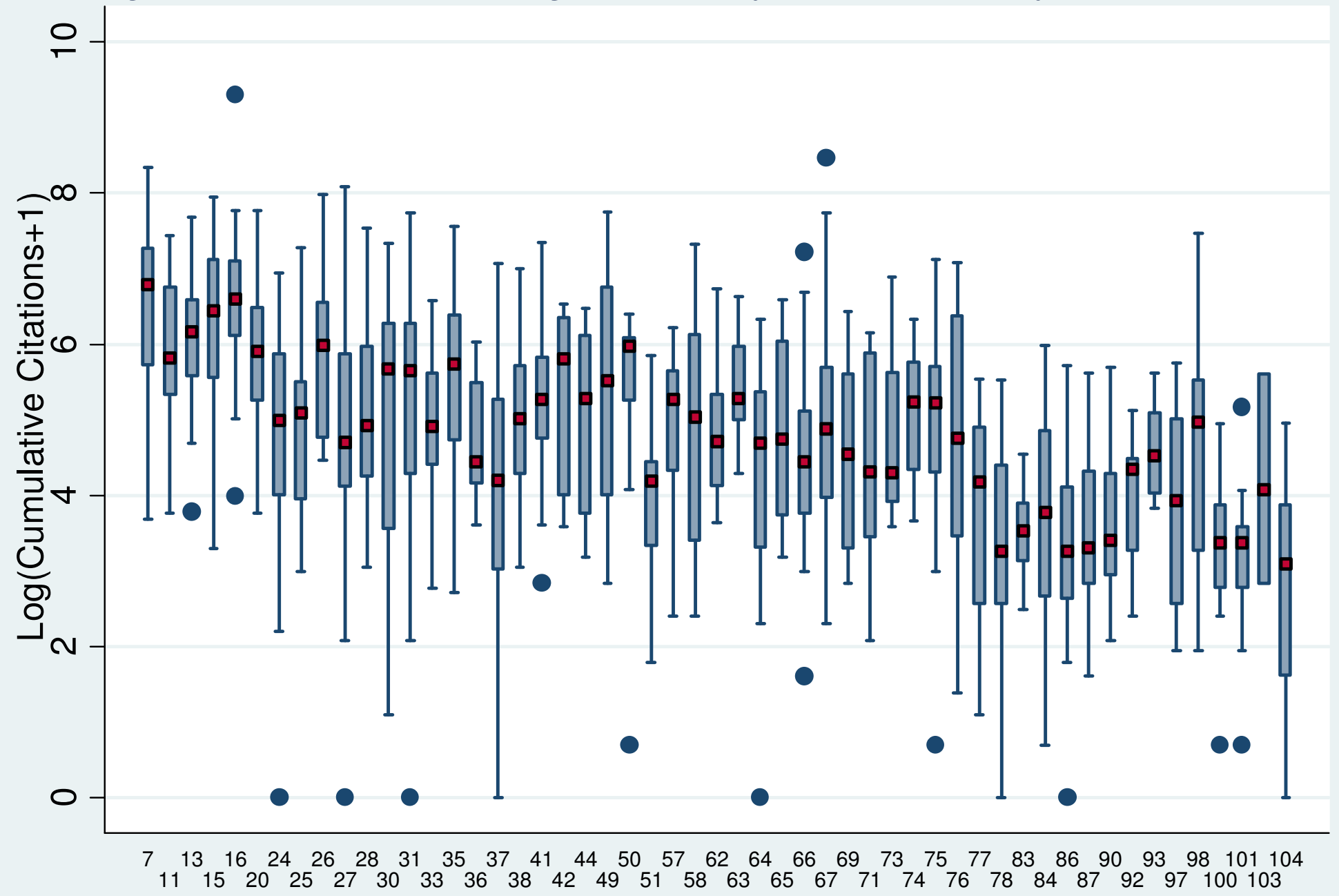


Figure 2: Distribution of Salaries for "mature" faculty, over NRC Rank

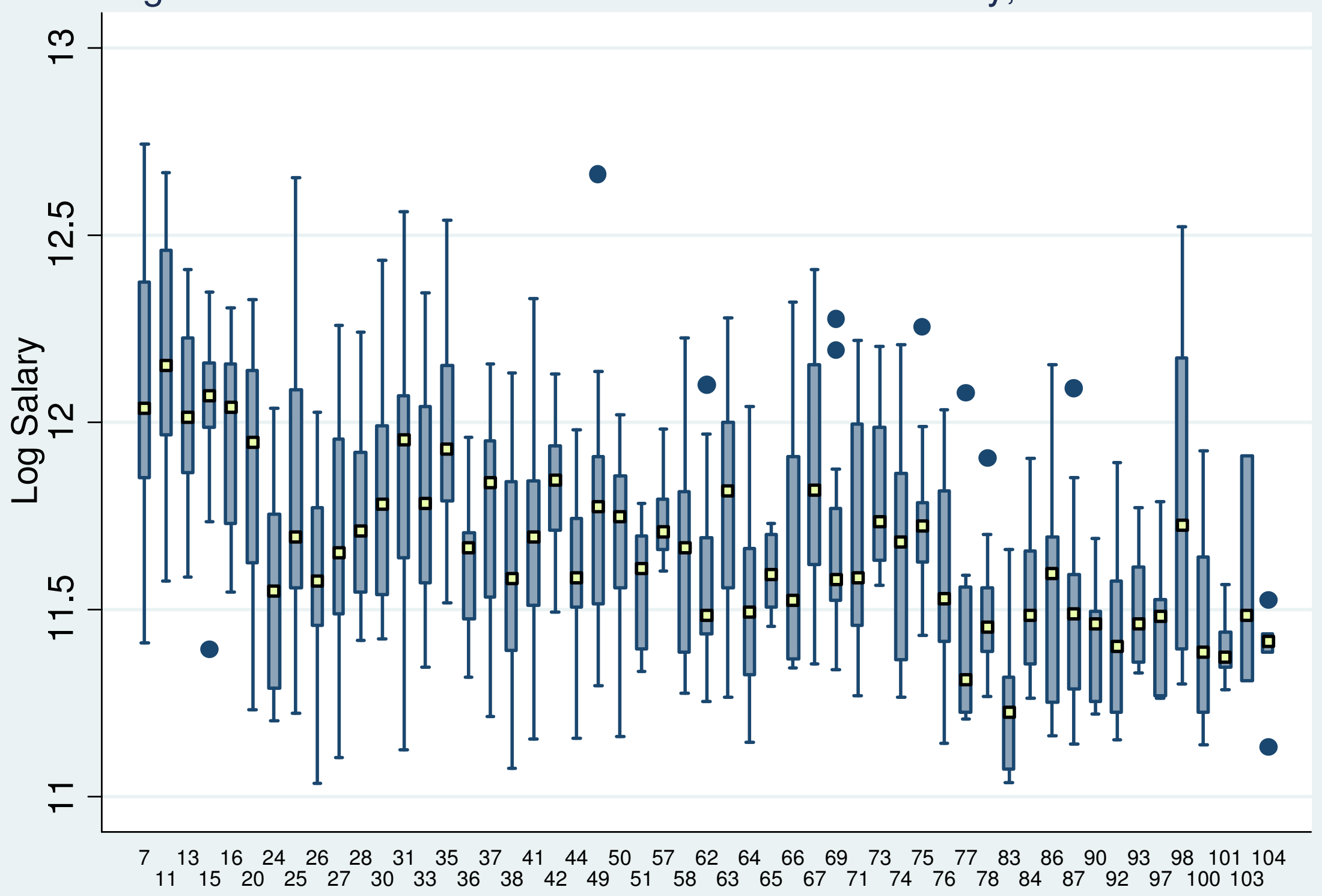

